KRZYSZTOF KOC

(D) https://orcid.org/0000-0001-9734-945X

Uniwersytet im. Adama Mickiewicza

Poznań

\title{
Tacy sami, ale inni... \\ O prawach człowieka na lekcjach języka polskiego
}

The same, but different...

About human rights in Polish classes

\begin{abstract}
The author of the paper shows how one may reflect on the essence of human rights, through the lens of reporters' stories, including in particular Ben Rawlence's book City of Thorns: Nine Lives in the World's Largest Refugee Camp. The paper encourages one to listen to the voice of refugees and to develop an interest in their lives in order to understand how they define their rights, what they derive them from, and how they judge their observance by the international community. In fact, these deliberations are connected with a problem which is important for contemporary education, namely how to shape a genuinely humanistic attitude among young Poles towards people from different cultures, who are additionally forced to leave their homes.
\end{abstract}

Key words: human rights, refugees, Polish language and culture education, reportage

Refleksja nad tekstami opowiadającymi o uchodźcach w ramach lekcji języka polskiego skłania do przemyślenia podstaw edukacji humanistycznej. Wymaga na przykład zdefiniowania naszego sposobu rozumienia i definiowania praw człowieka oraz zmusza do zajęcia określonego stanowiska wobec ludzi, których uznajemy za innych, obcych. Dyskusja ta może inicjować rozważania dotyczące tego, czy za przestrzeganie praw człowieka odpowiadaja przede wszystkim organizacje humanitarne, międzynarodowy system prawny, powołane do tego instytucje polityczne, społeczne czy religijne, czy też jest to odpowiedzialność spoczywająca na każdej osobie, stanowiąca kwestię jej indywidualnego etycznego wyboru. 


\section{Reporterskie opowieści \\ o wariantach uchodźczego losu}

Analiza tekstów opowiadających o uchodźcach i tzw. kryzysie migracyjnym, jeśli ma być rzetelną refleksją nad istota praw człowieka, musi być kontekstowa, przybliżająca młodym ludziom swoistość konkretnych miejsc, jak również ludzkich losów i konkretnych wydarzeń osadzonych w równie konkretnym czasie i uwzględniać towarzyszące im szersze tło geopolityczne. Nie ma bowiem jednej, uniwersalnej opowieści o uchodźcach, podobnie jak nie ma jednego modelowego profilu uchodźcy, skupiającego niczym w soczewce wszystkie możliwe warianty losów ludzi decydujących się z różnych powodów ${ }^{1}$ na opuszczenie ojczystych stron. Potwierdzenie tego spostrzeżenia można odnaleźć, przyglądając się różnorodnym perspektywom, z których współczesne reportaże literackie przybliżają te niełatwe do zrozumienia problemy. Część z nich koncentruje uwagę czytelników na tym, czym są obozy dla uchodźców, jak są zorganizowane, w jaki sposób się w nich żyje, jak ich mieszkańcy kształtują swoje życie i relacje z innymi. Opowiadają w tym kontekście także o przyczynach skłaniających poszczególnych bohaterów do poszukiwania schronienia w tychże miejscach, o czyhających na nich zagrożeniach, o przysługujących im prawach, o planach na przyszłość, o ich marzeniach i frustracjach, a także o postawie i oczekiwaniach wobec świata pozaobozowego. Takie ujęcie odnaleźć można choćby w książce Wojciecha Tochmana i Katarzyny Boni zatytułowanej Kontener oraz w relacji Bena Rawlence’a Miasto cierni. Najwięeszy obóz dla uchodźców.

Inne reportaże przedstawiaja próby przedostania się uchodźców do Europy oraz szlaki, którymi do niej zmierzaja, ukazując przy okazji proces uprzedmiotowienia człowieka, wykorzystywanie ludzkiej krzywdy przez przemytników, kurierów, przewodników i innych ludzi zainteresowanych czerpaniem korzyści materialnych z nielegalnego przerzucania jak największej liczby osób do ich ziemi obiecanej, czyli głównie świata Zachodu. Wiele

\footnotetext{
1 Przyczyny te są wymienione w Konwencji dotyczqcej statusu uchodźców sporządzonej w Genewie 28 lipca 1951 roku. Zgodnie z jej zapisami za uchodźcę uznaje się osoby, które „na skutek uzasadnionej obawy przed prześladowaniami z powodu swojej rasy, religii, narodowości, przynależności do określonej grupy społecznej lub z powodu przekonań politycznych przebywaja poza granicami państwa, którego są obywatelami, i nie mogą lub nie chcą z powodu tych obaw korzystać z ochrony tego państwa” (http://prawo.sejm.gov.pl/isap.nsf/download. xsp/WDU19911190515/O/D19910515.pdf [dostęp: 15.03.2019]).
} 
miejsca w tychże opowieściach zajmuje refleksja nad okrucieństwem losu, opis walki o przeżycie, rekonstrukcja ludzkich nadziei i oczekiwań skonfrontowana często z brutalną i smutną rzeczywistością. Z egzemplifikacją tego z kolei ujęcia można zetknąć się, czytając Łódź 370. Śmierć na Morzu Śródziemnym Annah Björk i Matthiasa Beijmy, Na południe od Lampedusy. Podróże rozpaczy Stefana Libertiego, Przez. morze. Z Syryjczykami do Europy Wolfganga Bauera, Lekarza z. Lampedusy. Opowieść o cierpieniu i nadziei Pietra Bartola i Lidii Tilotty czy Wielki prayplyw Jarosława Mikołajewskiego.

\section{Uchodźcy - wyzwanie edukacyjne}

Polonista, który chciałby podjąć wraz z uczniami próbę przyjrzenia się te$\mathrm{mu}$ jakże istotnemu problemowi współczesnego świata, ma więc bardzo trudne zadanie wymagające nie tylko odpowiednich studiów lekturowych, ale również znalezienia języka umożliwiającego wielostronną, pogłębiona, a jednak indywidualną analizę zagadnienia. Zarówno dla nauczyciela języka polskiego, jak i dla uczniów proponowany temat jest z reguły obcy (wiedza o nim jest fragmentaryczna, czerpana głównie z migawkowych przekazów medialnych) oraz obarczony ryzykiem uwikłania się w ideologiczne oraz polityczne spory, co może się zakończyć zarzutami o nieuzasadnioną indoktrynację młodzieży szkolnej.

Jeśli jednak uznamy, iż rdzeniem edukacji humanistycznej jest, jak pisze Zofia Agnieszka Kłakówna, otwieranie „możliwości szerszego, samodzielnego rozeznawania się w świecie, w różnorodności, niejednoznaczności i skomplikowaniu ludzkiego życia i ludzkich relacji” (2016, 138-139), to propozycja zainteresowania się na lekcjach języka polskiego losami uchodźców jest przede wszystkim jednym ze sposobów urzeczywistnienia podstawowych obligacji spoczywających na systemie szkolnictwa powszechnego. Kłakówna definiuje je następująco:

Edukacja tego rodzaju ma zatem dawać narzędzia umożliwiające samodzielną orientację w świecie oraz jego samodzielną konceptualizację $\mathrm{i}$ interpretację. Chodzi w niej o stawianie w centrum uwagi pytań o własną tożsamość i rozmaite przynależności, które się na nią składaja, oraz o istotę i naturę świata, w którym się żyje. (...) Ze świadomością jednak, że w to poszukiwanie wpisana jest niepewność co do rezultatów $(2016,140)$. 
Warto zwrócić uwagę, jak wiele metodycznego wysiłku, talentu i inicjatywy wymaga urzeczywistnienie takich oczekiwań wobec przedmiotu. Nauczyciel musi być autentycznie zainteresowany współczesnym światem, zafascynowany jego różnorodnością, ale i świadomy tkwiących w nim napięć, konfliktów, dramatycznych wyborów, przed którymi stają ludzie w różnych częściach globu. Powinien także spoglądać na otaczająca nas rzeczywistość w pespektywie znacznie szerszej niż etnocentryczna (polonocentryczna). Wiele zjawisk zachodzących w przestrzeniach mniej lub bardziej odległych od Polski ma bowiem znaczący wpływ na światoodczuwanie młodych ludzi, ich postrzeganie wartości, rozumienie inności, a w omawianym tu kontekście - na pojmowanie istoty praw człowieka. Trzeba pamiętać, iż najstaranniej przemyślany układ zadań czy lekcji podporządkowany namysłowi nad współczesnymi problemami nigdy jednak nie będzie ujmował ich całościowo, kompletnie, a zatem nigdy nie będzie zawierać odpowiedzi ostatecznych i niepodlegających zakwestionowaniu. Czy to jest wada wpisana w samą istotę procesu kształcenia? Niekoniecznie, pozwala bowiem ukazywać wieloperspektywiczność i związaną z nią różnorodność jako atrybuty myślenia (zob. Arendt 2016, 78-79) pozwalające ocalić człowieka przed skutkami ideologizacji oraz indoktrynacji upraszczających schematów przemawiających czasami językiem dyskryminacji oraz wykluczenia.

\section{Miasto cierni jako opowieść antropologiczna}

Przekładając te rozpoznania i założenia na język szkolnej praktyki, proponuję zatem przyjrzeć się jednej z opowieści o losie uchodźców. Jest nią Miasto cierni Bena Rawlence’a, książka opisująca obóz dla uchodźców w Dadaab w Kenii. Wartość edukacyjna tej publikacji polega między innymi na tym, iż pozwala przyjrzeć się uchodźczemu mikrokosmosowi z perspektywy ludzi żyjących w tymże obozie; poznać ich sposób myślenia, rozumienia świata, problemy, rozterki, marzenia, lęki, frustracje, plany. Analizę owej opowieści warto ukierunkować również na poszukiwanie odpowiedzi na to, czym sa prawa człowieka, komu przysługuja, pod jakim warunkiem i jak są urzeczywistniane. Do takiej koncepcji odczytania uprawnia nas sam autor, który następująco eksplikuje wyzwanie, przed jakim staną:

Trzy poprzednie lata [poprzedzające spotkanie Rawlence’a z członkami Rady Bezpieczeństwa Narodowego w Waszyngtonie, do którego doszło 
31 października 2014 roku - K.K.] spędziłem, badając życie mieszkańców obozu, a pięć lat wcześniej przedstawiłem raport na temat przestrzegania tam praw człowieka. Jak opisać różne oblicza tego miejsca ludziom, którzy nigdy go nie widzieli? Nazwa „obóz dla uchodźców” jest myląca. Dadaab założono w 1992 roku, żeby pomieścić dziewięćdziesiąt tysięcy osób uciekających przed wojną domową w Somalii. Po ćwierćwieczu, na początku 2016 roku, było niezaznaczoną na żadnych oficjalnych mapach półmilionową aglomeracją wielkości Nowego Orleanu, Bristolu czy Zurichu (Rawlence 2017, 16).

Warto zauważyć, że zwykle dyskusja dotycząca obrony praw człowieka dotyczy zbiorowości żyjących w warunkach i znajdujących się w okolicznościach uzasadniających podejrzenie, że prawa te moga być realnie zagrożone, a nawet świadomie łamane przez inne grupy, społeczności czy wspólnoty. Przybliżenie losu ludzi skazanych na uchodźstwo ludziom żyjącym w bezpiecznym, własnym, wolnym, względnie dostatnim świecie oferującym rozmaite możliwości rozwoju, gdzie chronione i gwarantowane sa podstawowe prawa przynależne każdemu człowiekowi, jest więc sporym wyzwaniem edukacyjnym. Aby się z nim zmierzyć, reportażysta konfrontuje oficjalną mapę współczesnego świata z mapą nieoficjalną, na której znajdują się miejsca nieobecne w powszechnej świadomości, nawet jeśli są tak gęsto zaludnione jak Dadaab. Ale to dopiero początek - znacznie trudniejsze jest pokonanie ignorancji i obojętności społeczeństw zachodnich, braku zainteresowania poruszanym problemem czy też przełamywanie stereotypów i wyobrażeń karmiących się przekazami medialnymi oraz ideologicznymi założeniami (Rawlence 2017, 16).

Reportażysta decyduje się pokazać tę trudną i skomplikowaną rzeczywistość od środka, uznajacc, że najbardziej wiarygodne świadectwo moga przedstawić ci, którzy są zmuszeni w niej żyć, a nierzadko są to bardzo młodzi ludzie (o czym można się przekonać, analizując na przykład listę bohaterów i ich krótkie charakterystyki zamieszczone na początku książki); niektórzy z nich przebywają tam od urodzenia albo od wczesnego dzieciństwa. Rawlence pisze o sytuacji bez wyjścia, w której się oni znaleźli:

Uchodźcy, schwytani w pułapkę somalijskiej wojny i niechętnego im świata, żeby przetrwać w obozie, muszą wyobrażać sobie inne życie. To wytrącające z równowagi doświadczenie, albowiem przeszłość, teraźniejszość i przyszłość przestają być na dłuższą metę bezpieczna przystania. Życie w tym mieście cierni to zarówno duchowa, jak i fizyczna pułapka, 
bo myśl krąży tu nieustannie między nierealnymi marzeniami a koszmarną realnością. Krótko mówiąc, trafiają tu wyłącznie kompletni straceńcy (Rawlence 2017, 19).

W ten sposób poznajemy charakterystyczne rysy uchodźczej egzystencji jej osadzenie w tymczasowości, zależność od innych oraz doświadczenie wykluczenia oraz odrzucenia (mimo zorganizowanej przez ONZ kosztownej pomocy), przeobrażające się nierzadko w poczucie doznanej krzywdy, niesprawiedliwości (co skrzętnie wykorzystuja przemytnicy oraz różnego pokroju fanatycy, jak na przykład islamscy terroryści z Asz-Szabab). Takiemu światoodczuwaniu sprzyja też lokalizacja obozu, a wyraża je trafnie pochodzenie jego nazwy:

Miasteczko wyrasta na płaskiej, czerwonej równinie tuż powyżej równika. Cierniste zarośla uparcie ciagną się setkami kilometrów w każdym kierunku. (...) W miejscowym dialekcie dadaab oznacza „miejsce twardego kamienia”, bo pięć centymetrów pod czerwonym piaskiem zaczyna się warstwa twardej jak diament skały. Pierwsi mieszkańcy nie mieli pojęcia, jak trafna okaże się ta nazwa (Rawlence 2017, 47-48).

Rawlence akcentuje nieprzyjazny charakter tego miejsca także poprzez opis obozu widzianego z lotu ptaka:

Obozy, ciagnące się na blisko osiemdziesięciu kilometrach kwadratowych, wyglądaja jak wielkie, czarno-srebrne, pożyłkowane czerwienia księżyce orbitujące wokół Dadaab. Czerwień to sieć polnych dróg, srebrem pobłyskuja $\mathrm{w}$ bezlitosnym słońcu blaszane dachy, a czerń to wszechmocny na pustyni materiał budowlany, jakim sa cierniste akacje (Rawlence 2017, 49).

Ta fotograficzna perspektywa oraz operowanie kolorami i porównaniami służy ukazaniu, z jednej strony, ogromu obozowego kompleksu (co uświadamia, jak wielkiej grupie ludzi przyszło doświadczać uchodźczej egzystencji), a z drugiej - jego lichości, prowizoryczności, ulotności, w której człowiek skazany jest raczej na walkę o przetrwanie niż jakąkolwiek formę godnego życia.

Potwierdzenie tego obrazu znaleźć można we fragmentach opisujących obozową przestrzeń. Współtworzą ja posterunki służb bezpieczeństwa, blokady drogowe, ogrodzenia $z$ drucianej siatki, fortyfikacje chroniące siedziby różnych agencji pomocowych, reflektory, niskie budynki z blachy, belek 
i czasami betonu, namioty. Mieszczą się tutaj wprawdzie także kina i piłkarskie kluby, hotele, szpitale i szkoły, ale brytyjski dziennikarz nie pozostawia żadnych złudzeń co do rzeczywistego charakteru opisywanego miejsca zorganizowanego na fundamencie dwóch podstawowych zasad:

W organizacji przestrzennej obozu dla uchodźców ważne są, jak w więzieniu, dwie rzeczy - widoczność i kontrola. Obóz ma strukturę instytucji karnej. I choć nie było przestępstwa, jest ono z góry brane w rachubę. Potulni i słabi uchodźcy robią na ogół to, co im się każe, w obliczu władzy tracą pewność, a o swych prawach mówia, jakby dopraszali się łaski (Rawlence 2017, 127).

Trwałym elementem uchodźczej tożsamości jest więc także brak poczucia prywatności i konieczność budowania relacji międzyludzkich w rzeczywistości pozbawionej zaufania i poczucia bezpieczeństwa. W tym świecie prawa człowieka są traktowane uznaniowo, a ich urzeczywistnienie nie jest niczym ani przez nikogo bezwzględnie gwarantowane. Naruszanie tychże praw nie niesie nieuchronnych oraz adekwatnych sankcji dla tych, którzy się tego dopuszczaja. To kolejny element opisywanej rzeczywistości, który trudno pojąć człowiekowi Zachodu, objętemu z reguły podstawową ochroną prawną i instytucjonalną.

\section{Prawa człowieka na światowym rynku}

Nic dziwnego zatem, że Rawlence wiele uwagi poświęca analizie mechanizmu uprzedmiotowienia uchodźców i ekonomizacji pomocy im udzielanej. Warto w szkolnej praktyce zwrócić szczególną uwagę właśnie na ten aspekt łamania praw człowieka. Mimo tego, że nie jest on tak „spektakularny” jak morderstwa, gwałty, pogromy, rozboje, aresztowania czy tortury, to może się okazać równie wyniszczający i dewastujący wartości uznawane za reprezentatywne dla postawy humanistycznej, o której w edukacji tyle się mówi. Okazuje się bowiem, iż niesienie pomocy humanitarnej może by elementem gospodarki wojennej - podlega ona bowiem reglamentacji, opodatkowaniu, przywłaszczeniu przez strony biorące udział w konflikcie, przejmujące bez trudu spora jej część na własne potrzeby, by kontynuować walki, w wyniku których liczba uchodźców (i potencjalnych beneficjentów organizacji niosących im pomoc) gwałtownie wzrasta. Nieodłącznym skutkiem ubocznym 
jest też korupcja, będąca często ceną za możliwość dostarczenia pomocy. Korzyści osiagają wówczas nie tylko poszczególni watażkowie, ale też służby bezpieczeństwa odpowiadające za utrzymanie porządku publicznego w obozie oraz politycy i urzędnicy wydający niezbędne pozwolenia (na przykład na rozbudowę obozowej infrastruktury, sprzątanie, zaopatrzenie i prowadzenie poszczególnych programów pomocowych) ${ }^{2}$.

Ekonomizacja dotyka w rezultacie samej idei niesienia bezinteresownej pomocy, która by móc ją uznać za przejaw miłosierdzia i empatii, powinna być przecież nieskażona nieczystymi intencjami i oczekiwaniami. Tak się jednak nie dzieje, wpisana jest w nią natomiast zastanawiająca i niepokojąca aksjologiczna ambiwalencja, którą Rawlence opisuje z przekąsem:

Wszystko w Dadaab jest przez kogoś „ofiarowane”, „dostarczone”, „ufundowane”, jakby po to, by przypominać uchodźcom, że nie mają niczego własnego. Nawet wozy policyjne są „ofiarowane przez UNHCR” (Rawlence 2017, 126).

W świetle takich i podobnych komentarzy zasadne jest zastanowienie się nad tym, na ile przyznawanie ludziom statusu uchodźców, niesienie im pomocy i osadzanie ich w obozach stanowi rzeczywisty przejaw szacunku dla ich godności, a na ile jest dość wyrafinowanym sposobem trzymania ich $z$ daleka od świata, który tę pomoc im oferuje, finansuje i projektuje. Odpowiedź na tę wątpliwość na pewno nie jest etycznie jednoznaczna, ale czy wytrącanie nas $z$ aksjologicznej strefy komfortu nie jest zadaniem prawdziwie humanistycznej edukacji? Naiwnością byłoby więc myśleć, że prawa człowieka można skutecznie chronić wyłącznie za pośrednictwem wyspecjalizowanych instytucji i towarzyszaccej im biurokracji, organizacji pozarządowych i polityków, dzięki odpowiednio zorganizowanej logistyce i powołanym do tego służbom. Wattpliwości formułowane przez Rawlence’a obnażają kruchość takiego sposobu myślenia i prowadzą nas w kierunku refleksji nad odpowiedzialnością indywidualną.

\footnotetext{
2 Bardzo krytyczną analizę niejasnych i dwuznacznych relacji wpisanych w międzynarodowy system niesienia pomocy humanitarnej przedstawia w swej pracy Linda Polman. W konkluzji pisze ona m.in. „Miej odwagę zepsuć atmosferę podczas narodowych akcji zbierania pieniędzy: zadawaj pytania pracownikom organizacji humanitarnych! Jeśli mówią, że ich działanie pomaga, zapytaj, kto otrzyma tę żywność, te leki? Niewinne ofiary, gubernatorzy wojskowi, a może i jedni, i drudzy? (...) Sprawdź, czy organizacje same mogą określać, kto otrzyma pomoc. Na obszarach, gdzie toczy się wojna, pracownicy organizacji humanitarnych niemal nigdy nie podejmują samodzielnie takich decyzji”' (Polman 2016, 197).
} 
Jak zatem kształtować poczucie więzi z ludźmi oddalonymi od nas o tysiące kilometrów, wywodzącymi się z zupełnie innego kulturowego świata, skazanymi na życie w takich miejscach jak Dadaab, z którymi trudno bezpośrednio wejść w jakiekolwiek rzeczywiste relacje, o niesieniu ewentualnej pomocy nawet nie wspominając? Alternatywa dla pokusy ich zignorowania i samousprawiedliwiającej się obojętności wydaje się rozwijanie za pośrednictwem szkolnej edukacji etyki solidarnościowej. Przejawiać się ona może w próbie zrozumienia sytuacji ludzi skazanych na uchodźczą egzystencję ${ }^{3}$. Uchodźca w tak zaprojektowanym procesie kształcenia powinien mieć twarz, imię, nazwisko, pochodzenie; znane nam powinny być jego motywacje, marzenia, lęki, a także jego sposób myślenia oraz podejmowane przez niego próby mierzenia się z własnym losem. Taką galerię postaci będących uchodźcami przedstawiają w swoich opowieściach wspomniani na początku reportażyści, w tym także Rawlence.

\section{Życie Tauane'a - studium przypadku}

Brytyjski dziennikarz interesuje się na przykład życiem Tauane’a, Somalijczyka, który przybył do Kenii w 1992 roku w wieku 7 lat (wraz ze swą rodzina), uciekając przed wojna. Nie przewidywał wówczas, że jego domem na następnych 25 lat stanie się miejsce położone w buszu, na pofałdowanym, gorącym, piaszczystym terenie pozbawionym naturalnych zasobów wodnych, zwane przez miejscowych Hagadera, stanowiące część obozowego kompleksu skupionego wokół Dadaab. Rawlence kreśli portret człowieka młodego, zaangażowanego społecznie, przedsiębiorczego, samodzielnego, potrafiącego w tych trudnych warunkach zadbać o swą niezależność finansowa (legalnie!), mającego marzenia i plany, których niestety nie był w stanie urzeczywistnić:

Tauane marzył o kupnie dużego domu, ale w obozie nie wolno było wznosić trwałych zabudowań. Chciał mieć samochód, ale na przeszkodzie stała ograniczona swoboda poruszania się. (...) Postąpił więc tak, jak wszyscy w Dadaab, którzy maja pieniądze - zakopał je (Rawlence 2017, 155).

\footnotetext{
${ }^{3}$ Ważne w tym kontekście byłoby też wyodrębnienie problemów wymagających zaangażowania społeczności międzynarodowej czy dokładniejsze przyjrzenie się działaniom podejmowanym na rzecz uchodźców, na przykład przez takie organizacje jak Polska Akcja Humanitarna.
} 
Jego umiejętności organizacyjne, zdolności przywódcze, uczciwość i gotowość do niesienia pomocy innym i współpracy sprawiły, że szybko zyskał szacunek i zaufanie obozowej społeczności i z czasem wyrósł na lidera, szczególnie wśród młodzieży. Jego proces dojrzewania był znacznie przyspieszony - wyzwania, przed którymi stanął, mocno się do tego przyczyniły. Musiał choćby zorganizować pomoc w czasie klęski głodu, a także negocjował z somalijskimi klanami uwolnienie porwanego w Hagaderze kenijskiego kierowcy. Podziw czytelnika budzi zakres spraw, w jakie Tauane się angażował (a były to takie kwestie, jak dystrybucja żywności, sprawy bezpieczeństwa, opieka zdrowotna, dostęp do wody, wywóz śmieci). Nie robił tego z pobudek idealistycznych czy ideologicznych. Tauane okazał się do szpiku kości realistą, świadomym zagrożeń czyhających na niego i wielu znanych mu ludzi. W tym właśnie realizmie zakorzeniony był jego plan na dalsze życie - wiedział bowiem, że docierając na szczyt obozowej hierarchii, natknie się automatycznie na „szklany sufit Dadaab” (Rawlence 2017, 160). A alternatywa dla ponurej przyszłości bez perspektyw rozwoju jest właściwie tylko możliwość kontynuowania życia gdzie indziej (zwłaszcza w Europie i w Ameryce Północnej). Zanim jednak podjął próbę opuszczenia obozu, zaangażował się czynnie w obronę praw człowieka, ,zbierając zeznania o gwałtach, pobiciach i grabieżach" dokonanych na uchodźcach przez kenijskich policjantów, a stanowiących odwet za terrorystyczne ataki dokonane na terenie obozu i wymierzone $\mathrm{w}$ kenijskie służby bezpieczeństwa $\mathrm{i}$ agencje pomocowe (nie udowodniono jednak, że były one inspirowane i wykonane przez ludzi zamieszkujących obóz). Świadectwem jego odwagi było pójście krok dalej, czyli zorganizowanie oddziałów samoobrony zabezpieczających Dadaab przez spodziewanymi atakami fanatyków z Asz-Szabab. W tym kontekście zupełnie zrozumiałe wydaje się przenikające go pragnienie wydostania się z obozu, który coraz bardziej stawał się dla niego pułapką. To pragnienie można by w zasadzie określić mianem syndromu nazywanego przez miejscowych buufis:

Słowo to ukute w Dadaab, oznacza tęsknotę za emigracją z obozu dla uchodźców. To rodzaj depresji, której źródłem jest niegasnąca nadzieja na inne życie, rzucająca zarazem cień na obecną egzystencję (Rawlence 2017, 203).

Dalsze jego losy, czyli ucieczka do Kenii, a potem nieoczekiwany powrót do Dadaab (spowodowany odczuciem bezradności oraz samotności) i podjęcie wcześniejszych obowiązków służących obozowej społeczności, poczucie wypalenia, rezygnacja z pełnionych funkcji, ponowny wyjazd do Kenii, 
praca na rzecz organizacji pozarządowej wspierającej uchodźców z Dadaab i poszkodowanych w somalijskim konflikcie, współpraca z agencjami pomocowymi i wzruszający powrót do ojczystej Somalii po ponad 20 latach od jej opuszczenia w roli koordynatora pomocy niesionej potrzebującym - wszystko to składa się na portret społecznika, samorządowca, człowieka z inicjatywa, zaangażowanego w działania obywatelskie, wrażliwego na cudze cierpienie. Jakże daleko temu portretowi do obrazu uchodźcy jako potencjalnego terrorysty, nastawionego roszczeniowo wobec świata Zachodu, marnotrawiącego niesioną mu pomoc, szukającego tylko okazji, by trafić do Europy.

To oczywiście tylko jeden z wielu wariantów uchodźczej biografii, ale za to rozbijający czarno-biały świat schematów, przekonań, przeświadczeń i narzucanych ocen jednoznacznie klasyfikujących takich ludzi, jak Tauane. Taka perspektywa przyglądania się losom konkretnych osób i analiza ich historii wydaje się jednak jedynym sensownym dydaktycznym pomysłem na to, jak podejmować w szkole namysł nad związkami między sytuacją uchodźców a sposobem rozumienia praw człowieka. Czy Tauane i podobne mu osoby maja prawo do poszukiwania lepszego życia, swobodę wyboru, jak i gdzie chcą żyć, czym chcą się zajmować? Czy maja prawo do poszukiwania niezależności finansowej, realizowania swoich życiowych planów, także w innym świecie niż ten, w którym się urodzili i wychowali? Czy mają prawo domagać się od międzynarodowej społeczności zainteresowania swoim losem i oczekiwać realnego wsparcia? Czy maja prawo urzeczywistniać swoje zdolności, wiedzę i kompetencje poza granicami obozu dla uchodźców, poza własnym krajem, poza własnym kontynentem? Nie jest łatwo udzielić jednoznacznej odpowiedzi na te pytania, ale samo ich zadawanie pozwala lepiej zrozumieć istotę praw człowieka wynikających z jego godności, czyniących uchodźcę równemu wszystkim innym ludziom ${ }^{4}$. Być może dzięki temu Inni będą uważani za takich samych, jak my.

\section{Literatura}

Arendt H., 2016, Kondycja ludžka, przeł. Lagodzka A., Warszawa.

Bartolo P., Tilotta L., 2017, Lekarz z Lampedusy. Opowieść o cierpieniu i nadziei, przeł. Stopa K., Kielce.

4 Trudno w tym kontekście odmówić racji Zygmuntowi Baumanowi, który pisał: „Mówiąc wprost: tendencja do zawieszania i uchylania moralnej odpowiedzialności za innych na granicy pomiędzy »nami« a »nimi« jest całkowicie i bezwarunkowo sprzeczna z »byciem moralnym«, pozostaje z moralnością w konflikcie” (2016, 93). 
Bauer W., 2016, Przez morze. Z Syryjczyleami do Europy, przeł. Kalinowska E., Wołowiec.

Bauman Z., 2016, Obcy u naszych drzwi, przeł. Mincer W., Warszawa.

Björk A., Beijmo M., 2017, Łódź 370. Śmierí na Morzu Śródziemnym, przeł. Kowadło-Przedmojska I., Warszawa.

Boni K., Tochman W., 2014, Kontener, Warszawa.

Kłakówna Z.A., 2016, Jezyk polski. Wyktady z metodyki. Akademicki podręznik myślenia o zawodzie szkolnego polonisty, Kraków.

Liberti S., 2013, Na potudnie od Lampedusy. Podróże rozpaczyy, przeł. Wyrembelski M., Wołowiec. Mikołajewski J., 2015, Wielki pryptyw, Warszawa.

Polman L., 2016, Karawana kryzysu. Za kulisami przemystu pomocy bumanitarnej, przeł. Jusewicz-Kalter E., Wolowiec.

Rawlence B., 2017, Miasto cierni. Największy obóz dla uchodźców, przeł. Kowalski S., Wołowiec.

\section{Netografia}

Konwencja dotyczqca statusu uchodźców, http://prawo.sejm.gov.pl/isap.nsf/download.xsp/WDU1 9911190515/O/D19910515.pdf [dostęp: 15.03.2019]. 